\begin{tabular}{|lc|}
\hline JUIRINßN & Jurnal Pendidikan Vokasi \\
PENDIDIKAN & Volume 9, No 2, June (172-184) \\
VOKASI & Online: http://journal.uny.ac.id/index.php/jpv \\
\hline \hline
\end{tabular}

\title{
EVALUATION OF THE IMPLEMENTATION OF WORKSHOP AND LABORATORY MANAGEMENT ON VOCATIONAL HIGH SCHOOL
}

\author{
Fuadillah Pangestu \\ Universitas Negeri Yogyakarta \\ Sukardi \\ Universitas Negeri Yogyakarta
}

\begin{abstract}
This research aims to reveal: the development of workshop and laboratory management implementation, also the suitability of facilities and infrastructure on Vocational High School in Banggai District, which refers to the indicator of good workshop and laboratory, according to the Directorate of Vocational Education. This research is evaluation research, which employs a goal free evaluation model and descriptive quantitative approach. The research sample involved in this study was 187 teachers and students. The data analysis technique used in this research was the average score and skewness. The result of this research shows that: (1) The workshop development is appropriate enough and good, yet it still needs further improvement with students to score at 81.19 and -0.229 also the teachers at 197.78 and -0.433. (2) The laboratory development is appropriate enough, and it still needs further improvement with students to score at 96.64 and 0.393, also the teachers at 209.03 and 0.36. (3) The suitability of the workshop's facilities and infrastructure is appropriate enough, and it still needs further improvement with the score at 250.205 and 0.549, and also the laboratory is appropriate enough and good, yet it still needs further improvement with the score at 252.80 and -1.694 .
\end{abstract}

Keywords: evaluation, laboratory management, workshop management

Permalink: http://dx.doi.org/10.21831/jpv.v9i2.25991

Contact Fuadillah Pangestu

fuadillahpangestu.2017@student.uny.ac.id

-Department of Technology and Vocational Education, Graduate School of Universitas Negeri Yogyakarta Jl. Colombo No. 1, Karangmalang, Depok, Sleman, Yogyakarta 55281, Indonesia 


\section{INTRODUCTION}

Education for a country is a quite significant matter in improving human resources to be able to compete with other countries. Fitriani $(2014$, p. 153) defines education is an inseparable part of national development, and it is the main element in national development. Article 3 of Law of Republic of Indonesia No. 20 of 2003 states that national education is aimed at enhancing ability and building a respected nation's character and civilization in accordance to enlighten the lives of the nation, and to develop students' potency in order to be religious human and believe in God the Almighty, having noble character, having high intelligence, being capable-creative, independent, and to become democratic and responsible citizens. Education is one of the ways to achieve prosperity in a developing country and to create a better society. According to Suyanta et al. (2018, p. 1), education is one of the factors that support the development of a country to develop and build its society to be better through education.

One of the ways to create a better society in Indonesia is through education system applied on Vocational High School, which is ruled in the Regulation of the Minister of Education and Culture No. 34 of 2018 stating that Vocational High School is a formal education on the secondary level of education that carries on the vocational program. According to Martono, Saputro, Wahyono, Laksono, and Isnantyo (2018, p. 2), education is one of the factors that support the development of a country to develop and build its society to be better through education. Estriyanto, Kersten, Pardjono, and Sofyan (2017, p. 28) also claim that the Vocational High School is a workoriented education at the secondary level of education in the national education system. The graduates of Vocational High School are skill-ready workers who have capabilities of success since its education program are measured from the employment acceptance level in its relation to industries or world of work.

Vocational education is a part of Technical and Vocational Education Training (TVET). Yasin, Nordin, Rahim, and Yunus (2014, p. 28) define vocational education is education that provides individuals with specific skills for a particular job field. TVET is aimed at preparing skill-ready workers, having entrepreneur skills, and competitive based on the vocational skills that have been chosen with the needs of industries world. TVET also has the same definition in preparing skill-ready workers in order to work in the workplace. Hadi, Hassan, Razzaq, and Mustafa (2015, p. 1163) also claim that Technical and Vocational Education Training (TVET) plays a role in producing workers with reflexes that allow them to interact with job duties in the organization of the workplace. The students' skills in Vocational High School must balance with the needs of the business or industry world. The unbalance amount of the needs in business or industries world can cause unemployment since there is an inequality of the skills owned by the students with the business or industries world. Based on the data provided by the Central Bureau of Statistics of Banggai district in 2018, there are 1,440 secondary-level school graduates, in which the vocational high school graduates are dominant. The standard competency for Vocational High School/Vocational Madrasah Aliyah graduates in Indonesia is adopted from the aim of national education, and the graduates profile in graduate area competence. Vocational High School/Vocational Madrasah Aliyah in Indonesia has a purpose as a vocational institution in Indonesia in preparing skillful workers who have skills based on the needs of business or industries world.

VHS or TVET has the purpose of building someone to have vocational skills in accordance to enable him or her to work in business or industries world and to develop the economic growth both private and national economy. Slamet (2010, p. 107) states that vocational education is one of the institutions to prepare the workers in the industry. Technical and Vocational Education and Training (TVET) plays a crucial role in transforming economies by providing a skilled human resource (Baryamureeba \& Karukuza, 2014, p. 7). Vocational skills that have been gained by the students in VHS or TVET will make them have an important role in coping with some challenges to achieve sustainable economic development. Majumdar (2012, p. 1) claims that TVET can play an instrumental role in developing a new generation of individuals who will face the challenge of achieving sustainable socio-economic development.

Entering the new era of Industry 4.0, the students of Vocational High School are expect- 
ed to have skills in which they are ready for the change. The vision of Industry 4.0 is to bring some new approaches, methodologies, and technologies. The vision of Industry 4.0 will bring not only new approaches but also the methodologies and technologies (Benešová \& Tupa, 2017, p. 2195). For vocational education in Indonesia in coping with Industry 4.0, the concept of competency has been converted into a capability that enables VHS graduates to have skills which suitable for the needs of new business or industries world. Samani (2018, p. 45) also has the same opinion about it. In coping with the industrial era 4.0, the concept of competency in vocational education must be converted into the capability to enable graduates to engage with the latest work patterns. In industrial revolution 4.0, the graduates are demanded to have more than one vocational skill. Dwiyanti, Ana, and Widianingsih (2018, p. 98) also state that in disruption and industry revolution 4.0 era, more skills must be mastered by them, such as social skills.

Industry 4.0 also expects the good and appropriate supporting curriculum for Vocational High School in which it is used for improving the suitable vocational skill that enables the graduates to work in industries or business world. In coping with Industry 4.0, the curriculum of Vocational High School has to be revised to adjust with the students' skills and the business and industries world. Janis and Alias (2017, p. 1052) also state that Vocational Education and Training (TVET) educators improvise the TVET curriculum structure with the aim of producing the technical graduates that are capable of working in the Industry 4.0 work environment. The curriculum in the vocational field should concern the needs of Industry 4.0. According to Durmus and Dağ 11 (2017, p. 1), curriculums need to be refreshed so that they can be integrated into the Philosophy of Industry 4.0 of the Vocational School laboratories.

The purpose of vocational education is to give students some provisions of good vocational skills and build them to be skill-ready workers or entrepreneurs. Practicing skills in laboratory and workshop is the media for students to understand and strengthen their lesson materials; it is also aimed to develop students' work orientation. The insufficient condition of laboratory and workshop is one factor that triggers to students' lack of curiosity and orienta- tion toward their work orientation (Syafrudie, 2016, p. 163). Facilities and infrastructures of Vocational High School in Indonesia have been ruled on the Regulation of the Minister of National Education No. 40 of 2008, about facilities and infrastructures to support the teaching-learning activity. Sajidan, Baedhowi, Triyanto, Totalia, and Masykuri (2018, p. 60) also claim that those factors would be the main guard of the teaching-learning process, especially for laboratory and workshop that has modern equipment and facilities based on the demand for science and technology development. The graduates of vocational high school (VHS) or TVET are trained to have good skills and training in a workshop or laboratory. According to Bakri and Zakaria (2018, p. 153), under TVET education, the graduates will undergo several skills and technical training in either laboratories or workshops. A laboratory or workshop has a different quality in which they can disturb the learning process, so the policymaker must cooperate with the industries party. Oviawe, Uwameiye, and Uddin (2017, p. 7) also state that TVET educational institutions must collaborate with the industry towards bridging the skill gap. The quality of vocational education can be seen from the effectiveness of all education systems; class, workshop, and laboratory. Referred to Lucas, Spencer, and Claxton (2012, p. 13), it is stated that the effectiveness of all education systems depends critically on the quality of teaching and learning in the classrooms, workshops, laboratories, and other spaces in which education takes place.

Substantially, Vocational High School is one of the education institutions aimed to prepare skill-ready graduates, having entrepreneur skill, intelligent, competitive, having nation identity, and capable to develop local wisdom and also to be able to compete in the global market (Sajidan et al., 2018, p. 1). A workshop or laboratory is a place that provides a simulation atmosphere for students to implement their theory that they have learned into real practice (Ghufron et al., 2018, p. 3). The improvement of skills in laboratories or workshops for students should be relevant to industrial needs. Anindo, Mugambi, and Matula (2016, p. 103) claim that it was also established that the relevance of training equipment influences the acquisition of employable skills. Laboratory or workshop as the primary facility 
for students in transferring their knowledge and skill development. Sharipova and Wesseler (2018, p. 27) conclude that workshops function to transfer some knowledge and to develop some skills or competencies. Laboratory and workshop in vocational education are facilities that form students' competencies. Wijanarka (2011, p. 1) believes that laboratories and workshops on vocational education are the primary facilities in the formation of student competence. Therefore, vocational education has a big role in building students' skills in which it is useful for them to work and to be an entrepreneur. A laboratory or workshop must be free from problems that can cause students or workers to have bad skills. Egbri and Chukwuedo (2013, p. 74) state the same thing that Technical Vocational Education and Training (TVET) is meant to infuse in the learners the appropriate skills needed to be self-employed or be employable, but the problem of ill-equipped laboratories/workshop culminating in poor skill. Workshop and laboratory are useful and important for students to help their teachers in conducting the learning process. Besides, workshop and laboratory is a facility in building a vocational skill based on competency skill needed by industries.

\section{RESEARCH METHOD}

This research is evaluation research employing a descriptive quantitative methodological approach. The model of this evaluation research is the goal free evaluation model. The research was conducted in three Vocational High Schools or Sekolah Menengah Kejuruan (SMK) in Banggai district; they are SMK Negeri 2 Luwuk, SMK Negeri 1 Toili, and SMK Negeri 1 Moilong. The population of the research was teachers and 363 of 11th-grade students. There were 187 samples from three Vocational High Schools in this research. The teachers and students that become the subjects of the research were determined using proportional random sampling technique. The technique of data collecting used in the research was by distributing a questionnaire to gain data from the teachers and students. Besides, there was an interview to obtain additional information directly from the respondents; they are the teachers/the chief of workshop/the chief of program and students.

\section{RESULTS AND DISCUSSION}

The result of the research can be seen by the improvement of workshop and laboratory at some Vocational High School in Banggai district on how far the improvement of implementation conducted in laboratory and workshop based on the standard of Vocational High School Directorate Supervisor. To observe the improvement of laboratory and workshop, the respondents used in the research were teachers and students. Therefore, the data of the research were divided into two, between teacher respondent and student respondent. In this research, there were six indicators used to measure the quality of the workshop and laboratory; namely, as follow practice area, atmosphere, temperature, lighting, maintenance, and work station. Meanwhile, to see the applicability of facilities and infrastructures in the workshop and laboratory, the researchers used an observation sheet.

Table 1. Table of Average Score and Skewness of Student-Respondent Workshop

\begin{tabular}{lcc}
\hline \multirow{2}{*}{ Indicator } & \multicolumn{2}{c}{ Workshop } \\
\cline { 2 - 3 } & $\begin{array}{c}\text { Average of } \\
\text { Score }\end{array}$ & Skewness \\
\hline Practice Area & 24.31 & 0.164 \\
Atmosphere & 4.27 & -1.091 \\
Temperature & 4.30 & -1.412 \\
Lighting & 4.33 & -1.456 \\
Maintenance & 8.36 & -0.533 \\
Workstation & 35.61 & -0.356 \\
\hline
\end{tabular}

In the research result in Table 1, it shows that there are two types of analysis used in observing the improvement of the workshop. If it is seen from the average of the score on the practice area in Vocational High School workshops in Banggai district, it can be concluded that the result of Vocational High School workshops in Banggai district has appropriate enough tendency with the average score at 24.31 from students as respondent. In addition, the researchers observed the practice area in the workshop, which is seen by the skewness with a positive result at 0.164 . It shows that it is necessary to improve the suitability of the practice area in vocational high school (VHS). The atmosphere in VHS in Banggai district, based on the research result, indicates that the result of the workshop atmosphere in the VHS 
in Banggai district has appropriate enough tendency if it is seen from the mean score at 4.27 from students as respondent. Besides, if it is seen from the atmosphere in the workshop, it has negative skewness at -1.091 . It shows that it is good to have an atmosphere in the workshop. The temperature in Vocational High School workshops in Banggai district has appropriate enough tendency if it is seen from the average score at 4.30 from students as respondents. In addition, this research observes the improvement of the practice area in which there is negative skewness at -1.412 . It shows that it is good to have temperature in the workshop.

Based on Table 1, the lighting in VHS workshops in Banggai district has appropriate enough tendency with the average score at 4.33 from students as respondents. Besides, if it is seen from the lighting in the workshop, it has a negative lighting score at -1.456 . It shows that it is good to have lighting in the workshop. From the research result, the maintenance in Vocational High School workshops in Banggai district has appropriate enough tendency with the average score at 8.36 from students as respondents. In addition, if it is seen from the maintenance in the workshop, it has negative maintenance at -0.533 . It shows that it is good to have maintenance in the workshop. Meanwhile, the workstation in VHS workshops in Banggai district has appropriate enough tendency with the average score at 35.61 from students as respondents. Besides, if it is seen from the workstation in the workshop, it has a negative workstation at -0.038 . It shows that it is good to have a workstation in the workshop.

Table 2. Average of Score and Skewness of Student-Respondent Laboratory

\begin{tabular}{lcc}
\hline \multirow{2}{*}{ Indicator } & \multicolumn{2}{c}{ Laboratory } \\
\cline { 2 - 3 } & $\begin{array}{c}\text { Average of } \\
\text { Score }\end{array}$ & Skewness \\
\hline Practice Area & 41.37 & -0.038 \\
Atmosphere & 3.80 & 0.008 \\
Temperature & 10.50 & -0.356 \\
Lighting & 3.53 & 0.138 \\
Maintenance & 8.36 & 0.247 \\
Workstation & 24.47 & 0.981 \\
\hline
\end{tabular}

Based on the research result in Table 2, it indicates that when we analyze the indicator findings of the research in the laboratory, there are two types of analysis, namely: the average of score and skewness, which is seen from its improvement. In accordance with the whole statements or questions on the indicators, the respondent of the research are the students. The practice area in Vocational High School laboratories in Banggai district shows that it has an appropriate enough tendency if it is seen from the average score at 41.73 of students as respondents. Besides, if it is seen from the practice area in the laboratory, which is seen from the skewness, it has a negative result with skewness at -0.038 . It shows that it is good for the practice area. The atmosphere in Vocational High School laboratories in Banggai district has appropriate enough tendency if it is seen from the average score at 3.80 from students as respondents. Besides, it can be concluded that the atmosphere in the laboratory if it is seen from the skewness, it has a positive result with skewness at 0.008 . It shows that it still needs further improvement in the suitability of the atmosphere in the laboratory. The temperature in Vocational High School in Banggai district has appropriate enough tendency if it is seen from the average score at 10.50 from students as respondents. Besides, it can be concluded that temperature in the laboratory if it is seen from the skewness, it has a negative result with skewness at -0.356 . It shows that it is good from the temperature.

The lighting in Vocational High School laboratories in Banggai district has appropriate enough tendency if it is seen from the average score at 3.53 from students as respondents. Besides, it can be concluded that the atmosphere in the laboratory if it is seen from the skewness, it has a positive result with skewness at 0.138 . It shows that it still needs further improvement from its suitability of lighting in the laboratory. The maintenance in Vocational High School laboratories in Banggai district has appropriate enough tendency if it is seen from the average score at 8.36 from students as respondents. Besides, it can be concluded that maintenance in the laboratory if it is seen from the skewness, it has a positive result with skewness at 0.247 . It shows that it still needs further improvement from its suitability of maintenance in the laboratory. The workstation in Vocational High School laboratories in Banggai district has appropriate enough tendency if it is seen from the average score at 24.47 from students as respondents. Besides, it can be concluded that the workstation in the 
laboratory if it is seen from the skewness, has a positive result with skewness at 0.981 . It shows that it still needs further improvement from its suitability of workstation in the laboratory.

Table 3. Table Average of Score and Skewness of Teacher-Respondent Workshop

\begin{tabular}{lcc}
\hline \multirow{2}{*}{ Indicator } & \multicolumn{2}{c}{ Workshop } \\
\cline { 2 - 3 } & $\begin{array}{c}\text { Average of } \\
\text { Score }\end{array}$ & Skewness \\
\hline Practice Area & 96.83 & -0.568 \\
Atmosphere & 9.52 & -0.093 \\
Temperature & 6.48 & -0.299 \\
Lighting & 19.35 & -0.452 \\
Maintanance & 8.36 & -0.186 \\
Workstation & 49.83 & -0.262 \\
\hline
\end{tabular}

The research result in Table 3 shows that in analyzing the findings of the indicators in the workshop, there are two types of analysis, which are average of score and skewness that is seen from the development perspective. Based on the entire result of statements or questions on this indicator in which the respondent is the teacher, the practice area takes place on the workshop of Vocational High School in Banggai district. According to the result, it can be concluded that the result of the practice area on the workshop of Vocational High School in Banggai district has an appropriate enough tendency if it is seen from the average score 96.83 from the teacher as the respondent. Moreover, this research sees the development of the practice area in the workshop, which is seen from skewness that shows the negative results with skewness at -0.568 . The result shows that the practice area is already good. The atmosphere on the workshop of Vocational High School in Banggai district based on the result can be concluded that the atmosphere on the workshop of Vocational High School in Banggai district is considered appropriate enough if it is seen from the average score at 9.52 from the teacher as respondent. In addition, this research sees the development of the atmosphere in the workshop, which is seen from skewness that shows the negative result with skewness -0.093 . The result shows that the atmosphere in the workshop is good, yet it still needs further improvement of the atmosphere suitability in the workshop. The temperature on the workshop of
Vocational High School in Banggai district based on the result can be concluded that the temperature on the workshop of Vocational High School in Banggai district has an appropriate enough tendency if it is seen from the average score at 96.83 from the teacher as respondent. Furthermore, this research sees the development of the temperature in the workshop, which is seen from skewness that shows the negative result with skewness at -0.299 . The result shows that the temperature in the workshop is considered good, yet it still needs further improvement of the temperature suitability in the workshop.

The lighting on the workshop of Vocational High School in Banggai district based on the result can be concluded that the result of the lighting on the workshop of Vocational High School in Banggai district has an appropriate tendency if it is seen from the average of the score at 15.78 from the teacher as respondent. Besides, this research sees the development of the lighting in the workshop, which is seen from skewness that shows the negative result with skewness -0.452 . The result shows that the lighting in the workshop is considered good. The maintenance on the workshop of Vocational High School in Banggai district based on the result can be concluded that the result of the maintenance on the workshop of Vocational High School in Banggai district has an appropriate enough tendency if it is seen from the average of the score at 19.35 from the teacher as respondent. Also, in this research sees the development of the maintenance on the workshop of Vocational High School in Banggai district that is seen from skewness that shows the negative result with skewness at 0.186 . The result shows that the maintenance of the workshop is considered good. The workstation on the workshop of Vocational High School in Banggai district based on the result can be concluded that the result of the workstation on the workshop of Vocational High School in Banggai district has an appropriate enough tendency if it is seen from the average score at 49.83 from the teacher as respondent. Further, this research sees the development of the workstation on the workshop, which is seen from skewness that shows the negative result with skewness at -0.262 . The result shows that the workstation in the workshop is considered good. 
Table 4. Table Average of Score and Skewness on Teacher-Respondent Laboratory

\begin{tabular}{lcc}
\hline \multirow{2}{*}{ Indicator } & \multicolumn{2}{c}{ Laboratory } \\
\cline { 2 - 3 } & $\begin{array}{c}\text { Average of } \\
\text { Score }\end{array}$ & Skewness \\
\hline Practice Area & 120.83 & 0.152 \\
Atmosphere & 12.00 & -0.399 \\
Temperature & 6.47 & -0.671 \\
Lighting & 11.57 & 0.467 \\
Maintenance & 8.36 & 0.159 \\
Workstation & 47.03 & -0.330 \\
\hline
\end{tabular}

The result of the research in Table 4 shows that in analyzing the findings of the indicators in the laboratory, there are two types of analysis, which are average of score and skewness that is seen from the development perspective. Based on the entire result of statements and questions on the indicator in which the respondent of this research is the teacher, the practice area on the laboratory of VHS in Banggai district has an appropriate enough tendency if it is seen from the average score at 120.83 from the teacher as respondent. Moreover, this research sees the development of the practice area on the laboratory seen from skewness that shows the positive result with skewness 0.152 . The result shows that it still needs further improvement in the practice area suitability in the laboratory. The atmosphere in the laboratory of VHS in Banggai district, based on the result, the atmosphere in the laboratory of VHS in Banggai district has an appropriate enough tendency if it is seen from the average of the score at 12.00 from the teacher as respondent. In addition, this research sees the development of the atmosphere in the laboratory that is seen from skewness that shows the negative result with skewness at -0.399 . The result shows that the atmosphere in the laboratory is considered as good. The temperature in the laboratory of VHS in Banggai district based on the result can be concluded that the temperature results in the laboratory of VHS in Banggai district have an appropriate enough tendency if it is seen from the average score at 6.47 from the teacher as respondent. Furthermore, this research sees the development from the temperature on the laboratory that is seen from skewness that shows the negative result with skewness at -0.671 . The result shows that the temperature in the laboratory is considered good.
The lighting in the laboratory of Vocational High School in Banggai district has an appropriate enough tendency if it is seen from the average score at 12.27 from the teacher as respondent. Further, this research sees the development of the lighting on the laboratory that is seen from skewness that shows the positive result with skewness at 0.467 . The result shows that it still needs further improvement in the suitability of the lighting in the laboratory. The maintenance in the laboratory of Vocational High School in Banggai district based on the result it can be concluded that it has an appropriate enough tendency if it is seen from the average score at 11.57 from the teacher as respondent. Besides, this research sees the development of the maintenance in the laboratory that is seen from skewness that shows the positive result with skewness at 0.159 . The result shows that it still needs further improvement in the maintenance suitability in the laboratory. Also, this research sees the development of the maintenance in the laboratory that is seen from skewness that shows the positive result with skewness at 0.159 . The result shows that it still needs further improvement in the maintenance suitability in the laboratory. Workstation in the laboratory of Vocational High School in Banggai district based on the result can be concluded that the result of the work station in the laboratory of Vocational High School in Banggai district has an appropriate enough tendency if it is seen from the average of the score at 47.03 from the teacher as respondent. Furthermore, this research sees the development of workstations in the laboratory that is seen from skewness that shows the negative result with skewness -0.330 . The result shows that the workstation is considered good in the laboratory.

Table 5. Table Average of Score and skewness of Student-Respondent Workshop and Laboratory

\begin{tabular}{lcc}
\hline X1 & $\begin{array}{c}\text { Average of } \\
\text { Score }\end{array}$ & Skewness \\
\hline Workshop & 81.19 & -0.229 \\
Laboratory & 96.64 & 0.393 \\
\hline
\end{tabular}

Based on Table 5, the average score of the students' achievement is 81.19 . It figures out that the workshop is appropriate enough and the skewness score is at -0.229 , which figures out that it still needs improvement on 
five indicators, including atmosphere, temperature, lighting, maintenance, and workstation, to create proper and adequate workshop that meets the main standards in developing good and adequate workshop also tools necessity or supportive building in the continuity of workshop and laboratory for the students in practicing. In creating a good workshop, there are six indicators that become the basic standard to refer to a good workshop, according to the Directorate of Vocational Education stated in a book entitled Modernisasi Bengkel Laboratorium Abad 21. Furthermore, according to the Regulation of the Minister of National Education No. 40 of 2008 on the standard of facilities and infrastructure for Vocational Secondary School/Vocational Madrasah Aliyah (SMK/ MAK), a school, especially Vocational High School (VHS), must provide adequate workshop or practice area so that it makes the students feel comfortable when they are practicing. A workshop is a place where the students are gaining professional vocation skills so that they are ready to work by exploiting their in-line skills with the competence in industrial and entrepreneurship world. In fact, workshops and laboratories on Vocational High School are the facilities and places that support the main teaching-learning activity in developing their skills. Ismara and Prianto (2017, pp. 206-207) claim that a workshop or laboratory is a place that supports the training activity and a place to elevate skills, in order to develop the comprehension and skills that suit the areas of expertise. It also has a function as a place that provides completeness of the theoretical learning that has been accepted so that both theory and practice are not two separate things, but integrated one another. Based on the data in Table 5, the workshop is being analyzed by using goal free evaluation model that the emerging weaknesses to achieve the main goal that is seen in this model. According to the students, the workshop still needs further improvement so that it can be a good and comfortable place for the students. The inadequacy of the workshop management implementation on Vocational High School has become the consideration in the future in order to meet the criteria as a good and comfortable workshop for the students in practicing that refers to the standard from the Directorate of Vocational Education and a workshop that becomes the replica of the industrial world.
Laboratory, based on the average score at 96.64, is considered appropriate enough. Skewness 0.393 figures out that the laboratory still needs further improvement on two indicators, which are practice area and temperature, to develop proper and adequate, in addition to the tools necessity or supportive building, which support the continuity of the laboratory for the students in practicing. There are six indicators of the appropriate laboratory that become the reference from the Directorate of Vocational Education, as stated on a book entitled Modernisasi Bengkel Laboratorium Abad 21 and the Regulation of the Minister of National Education No. 40 of 2008 on the standard of facilities and infrastructure for Vocational Secondary School/Vocational Madrasah Aliyah. A laboratory is a place where the students doing some experiments and improving their skills, in this case, is the theory that has been taught. The laboratory is also being designed in such a way to become a place where the students can improve their skills optimally that meet industrial needs. Martono et al. (2018, p. 60) define that vocational high school should conduct synchronization of their laboratory with the industrial condition, so that the students can practice by using suitable system that is used in the industry and it is expected that the competence of Vocational High School graduate is relevant with the industrial needs. Based on the data on Table 5 in which the workshop is being analyzed by using goal free evaluation model that the emerging weaknesses to achieve the main goal that is seen on this model. According to the students, the laboratory still needs further improvement so that it can be a good and comfortable place for the students.

Table 6. Table Average of Score and Skewness of Teacher-Respondent Workshop and Laboratory

\begin{tabular}{lcc}
\hline X1 & $\begin{array}{c}\text { Average of } \\
\text { Score }\end{array}$ & Skewness \\
\hline Workshop & 197.78 & -0.433 \\
Laboratory & 209.03 & 0.36 \\
\hline
\end{tabular}

Based on the result of the research in Table 6, in which the teacher as the respondent, the average score of the workshop at 197.78 is considered as appropriate enough, and skewness at -0.433 on both tools necessity or the supportive building for the teacher to teach the 
students to practice their skill that covers six indicators that become the basic standard to refer a good workshop according to the Directorate of Vocational Education. A workshop is a place where the students gain professional vocation skills so that they are ready to work by exploiting their in-line skills with the competence in industrial and entrepreneurship world. The workshop, from the result above, if it is being analyzed by using goal free evaluation model that the emerging weaknesses to achieve the main goal that is seen on this model. According to data in Table 6, the workshop still has some weaknesses in order to meet the criteria of a good workshop as a place to improve not only the vocation skills but also to produce good quality goods which can be sold and become the students' provision to become an entrepreneur. Ghufron et al. $(2018$, p. 1) state that a workshop is not only just a place to conduct an experiment, but also a place to conduct serious tasks that have a real product. The inadequacy of the workshop management implementation on Vocational High School has become the consideration in the future in order to meet the criteria as a good and comfortable workshop for the teacher in teaching that refers to the standard form of the Directorate of Vocational Education and a workshop that become the replica of the industrial world.

Laboratory, based on the average score at 209.03, is considered as appropriate enough, and skewness at 0.36 still needs further improvement on three indicators, which are atmosphere, temperature, and workstation from the tools necessity or supportive building that support the continuity of the laboratory for the teacher in teaching. A good laboratory in this research has six indicators that refer to the criteria from the Directorate of Vocational Education. The role of a laboratory on Vocational High School is a place in which the teacher implements scientific teaching-learning activity with the students. Suyanta et al. (2018, p. 83) also define that laboratory is a place to conduct scientific research, experiment, measurement, or scientific training. The laboratory, based on the result, if it is analyzed by using a goal free evaluation model, the inadequacy that emerges to achieve the main purpose is the thing that is seen from the model. Based on Table 6, the laboratory is considered as appropriate enough, yet it still has some inadequacy, and it still needs further improve- ment to meet the criteria of good and comfortable laboratory for the teacher to implement teaching-learning activity. The inadequacy of the laboratory management implementation on Vocational High School has become the consideration in the future in order to meet the criteria as a good and comfortable workshop for the teacher in teaching that refers to the standard form of the Directorate of Vocational Education and a workshop that becomes the replica of the industrial world.

Table 7. Table Average of Score the Facilities and Infrastructure Suitability in Workshop and Laboratory

\begin{tabular}{lcc}
\hline X1 & $\begin{array}{c}\text { Average of } \\
\text { Score }\end{array}$ & Skewness \\
\hline Workshop & 250.20 & 0.549 \\
Laboratory & 252.80 & -1.694 \\
\hline
\end{tabular}

Based on the research result in Table 7, the average score at 250.20 is considered appropriate enough. Meanwhile, if it is seen from the skewness at 0.549 , the suitability of facilities and infrastructure according the $\mathrm{Di}$ rectorate of Vocational Education still needs further improvement on nine standards, covering building standard, door standard, partition standard, hearing-comfort standard, vent and heat standard, disaster mitigation standard, energy efficiency standard, and additional facilities standard in developing good and proper workshop. In addition, not only the tools necessity, but also the supportive building that supports the workshop continuity for the teacher in teaching and the students in their practice covering 16 indicators that become the basic standard that should be noticed by the workshop and laboratory manager. A workshop is a place where the teacher implements the teaching-learning process, and the students are practicing to obtain professional vocation skills so that they are ready to work by exploiting their in-line skills with the competence in the industrial and entrepreneurship world. The workshop at three different Vocational High School (VHS) in Banggai district consists of 10 study programs. Based on the data, if it is being analyzed by using goal free evaluation model, it only focuses on the weaknesses, not the main purpose, that emerges when the program is being implemented. Based on the data in Table 7 , those 10 study programs have a workshop 
that still needs further improvements in developing a good and comfortable workshop to facilitate the teacher in teaching and the students to easily improve their vocation skills without any burden which can be emerged from the condition of the workshop.

Based on the research result in Table 7, the average score achievement at 252.80 of the suitability of the facilities and infrastructure in the laboratory, according to the Directorate of Vocational Education, is considered appropriate enough. Meanwhile, if it is seen from the skewness at 1.649, the laboratory is considered good, yet it still needs further improvement on eight out of 16 indicators which cover the building standard, partition standard, sightcomfort standard, energy efficiency standard and additional facilities standard. If it is seen in creating good and proper laboratory and the necessity of the tools, also the supportive building that support the workshop continuity for the teacher in implement teaching-learning activity and the students in their practice, there are 16 indicators that become the basic standard according to the Directorate of Vocational Education that should be noticed by the workshop and laboratory manager.

The laboratory facilities and infrastructure on Vocational High School have a role as a place that makes the teacher who implements the teaching-learning activity and the students who are practicing their skills obtain professional vocation skills so that they are ready to work by exploiting their in-line skill with the competence in industrial and entrepreneurship world. Susanto and Sudira (2016, p. 57) state it is important to have the practice facilities and infrastructure in order to build the students' competency in vocational education. The laboratory at three different Vocational High School (VHS) in Banggai district consists of five study programs. Based on the data, if it is being analyzed by using goal free evaluation model, it only focuses on the weaknesses, not the main purpose, that emerges when the program is being implemented. Based on the data skewness -1.694 in Table 7, those five study programs have a laboratory that still needs some improvements in order to meet the criteria of good and comfortable laboratory to facilitate the teacher in teaching and the students to easily improve their vocation skills without any burden which can be emerged from the condition of the laboratory.

\section{CONCLUSION}

Based on the result of the research and the discussion, the workshop on Vocational High School (VHS) in Banggai district, according to students as respondents, still needs further improvement on the practice area to create proper and adequate workshop that meets the main standards in developing good and comfortable in order to achieve the main goal of workshop itself. Meanwhile, according to the teacher-respondent, the workshop is already proper and good. The laboratory on VHS in Banggai district is considered appropriate enough, yet it still needs further improvement to create a proper and adequate workshop that meets the main standards in developing a good and comfortable workshop in order to achieve the main goal of the workshop itself. The laboratory on VHS in Banggai district still needs further improvement if it is seen from four indicators which are atmosphere, lighting, maintenance, and workstation from studentrespondents. Meanwhile, the laboratory on VHS in Banggai district still needs further improvement if it is seen from three indicators, which are the practice area, lighting, and maintenance from teacher-respondent.

The suitability of workshop facilities and infrastructure on VHS in Banggai district that the suitability of the facilities and infrastructure from the entire 10 study programs on VHS in Banggai district still needs further improvement if it is seen from nine out of 16 indicators which are the building standard, door standard, partition standard, hearing-comfort standard, vent and heat standard, disaster mitigation standard, energy efficiency standard, and additional facilities standard.

The suitability of workshop facilities and infrastructure figure out, if it is seen from 16 indicators, that the suitability of the facilities and infrastructure from the entire five study programs on VHS in Banggai district still needs further improvement if it is seen from eight indicators, including building standard, partition standard, sight-comfort standard, disaster mitigation standard, tools and machine standard, energy efficiency standard, and additional facilities standard. The conditions become the implication for the entire school elements to continuously coordinate between the school manager in forming good workshop and laboratory that meets the standard according to 
the Directorate of Vocational Education and the Regulation of the Minister of National Education No. 40 of 2008.

\section{REFERENCES}

Anindo, J., Mugambi, M. M., \& Matula, P. D. (2016). Training equipment and acquisition of employable skills by trainees in public technical and vocational education and training institutions in Nairobi County, Kenya. International Journal of Advanced Research in Education \& Technology (IJARET), 3(4), 103-110. Retrieved from http://ijaret.com/wp-content/them es/felicity/issues/vol3issue4/mugambi.p df

Bakri, A., \& Zakaria, I. H. (2018). Uplifting the function of maintenance management towards sustainable performance of laboratory and workshop in TVET institutions. The Journal of Social Sciences Research, 6(Special Issue), 153-160. https://doi.org/10.32861/jssr. spi6.153.160

Baryamureeba, V., \& Karukuza, W. (2014). The role of TVET in building regional economies. International Journal of Vocational Education and Training, 22(1), 7-15. Retrieved from http:// hdl.voced.edu.au/10707/430424

Benešová, A., \& Tupa, J. (2017). Requirements for education and qualification of people in industry 4.0. Procedia Manufacturing, 11, 2195-2202. https:// doi.org/10.1016/J.PROMFG.2017.07.3 66

Durmus, A., \& Dağl1, A. (2017). Integration of vocational schools to industry 4.0 by updating curriculum and programs+. International Journal of Multidisciplinary Studies and Innovative Technologies, 1(1), 1-3. Retrieved from https://dergipark.org.tr/ tr/download/article-file/372843

Dwiyanti, V., Ana, A., \& Widianingsih, I. (2018). Industrial education impact on vocational student social skills. Innovation of Vocational Technology Education, 14(2), 98-103. https:// doi.org/10.17509/invotec.v14i2.14362
Egbri, J. N., \& Chukwuedo, S. (2013). Reengineering technical vocational education and training (TVET) in Nigeria through school-industry collaboration for capacity building. Nigerian Vocational Association Journal, 18(1), 74-82.

Estriyanto, Y., Kersten, S., Pardjono, P., \& Sofyan, H. (2017). The missing productive vocational high school teacher competency standard in the Indonesian education system. Journal of Technical Education and Training, 9(1), 26-44. Retrieved from https://publisher. uthm.edu.my/ojs/index.php/JTET/articl e/view/1499

Fitriani, K. (2014). Pengaruh motivasi, prestasi belajar, status sosial ekonomi orang tua dan lingkungan sekolah terhadap minat melannjutkan pendidikan ke perguruan tinggi pada siswa kelas XII Akuntansi SMK Negeri 1 Kendal. Economic Education Analysis Journal, 3(1), 152159. Retrieved from https://journal. unnes.ac.id/sju/index.php/eeaj/article/vi ew/4229

Ghufron, A., Suwarna, S., Sudiyatno, S., Sunarto, S., Andayani, S., Setiadi, B. R., \& Ismara, I. (2018). Modernisasi bengkel dan laboratorium kejuruan abad 21. Jakarta: Directorate of Vocational Education, Directorate General of Primary an Secondary Education, Ministry of Education and Culture. Retrieved from http://psmk. kemdikbud.go.id/konten/4232/modernis asi-bengkel-dan-laboratorium-kejuruanabad-21

Hadi, M. Y. A., Hassan, R., Razzaq, A. R. A., \& Mustafa, M. Z. (2015). Application of thinking skills in career: A survey on technical and vocational education training (TVET) qualification semiprofessional job duties. Procedia Social and Behavioral Sciences, 211, 1163-1170. https://doi.org/10.1016/ J.SBSPRO.2015.11.155

Ismara, I., \& Prianto, E. (2017). Bagaimanakah agar laboratorium dan bengkel pendidikan vokasi menjadi nyaman, selamat dan sehat? Yogyakarta: UNY Press. Retrieved from http://psmk. 
kemdikbud.go.id/konten/2705/bagaima na-agar-laboratorium-dan-bengkelpendidikan-vokasi-menjadi-nyamanselamat-dan-sehat

Janis, I., \& Alias, M. (2017). A systematic literature review: Human roles, competencies and skills in industry 4.0. In Proceeding of Asia International Multidisciplinary Conference 2017 (pp. 1052-1072). Johor Bahru: Universiti Teknologi Malaysia. https://doi.org/ 10.15405/epsbs.2018.05.84

Law of Republic of Indonesia No. 20 of 2003 on National Education System (2003).

Lucas, B., Spencer, E., \& Claxton, G. (2012). How to teach vocational education: A theory of vocational pedagogy. London: City \& Guilds Centre for Skills Development. Retrieved from https:// www.educationinnovations.org/sites/de fault/files/How-to-teach-vocationaleducation.pdf

Majumdar, S. (2012). Integrating sustainable development in TVET curriculum. In The 11th UNESCO-APEID International Conference (pp. 1-14). Bangkok: UNESCO Bangkok. Retrieved from https://www.voced.edu. au/content/ngv\%3A54369

Martono, T., Saputro, H., Wahyono, B., Laksono, P. W., \& Isnantyo, F. D. (2018). Optimalisasi kompetensi lulusan SMK dalam industri/teknologi terapan. Jakarta: Directorate of Vocational Education, Directorate General of Primary an Secondary Education, Ministry of Education and Culture. Retrieved from http://psmk.kemdikbud. go.id/konten/4121/optimalisasikompetensi-lulusan-smk-dalamindustri-teknologi-terapan

Oviawe, J. I., Uwameiye, R., \& Uddin, P. S. O. (2017). Bridging skill gap to meet technical, vocational education and training school-workplace collaboration in the 21 st century. International Journal of Vocational Education and Training Research, 3(1), 7-14. https:// doi.org/10.11648/j.ijvetr.20170301.12

Regulation of the Minister of Education and Culture No. 34 of 2018 on the national standard of education in vocational secondary school (2018). Republic of Indonesia. Retrieved from http://www. smkn3bandung.sch.id/wp-content/ uploads/2018/12/Permen-34-Tahun2018-Websiteedukasi.com-1.pdf

Regulation of the Minister of National Education No. 40 of 2008 on the standard of facilities and infrastructure for Vocational Secondary School/ Vocational Madrasah Aliyah (2008). Republic of Indonesia.

Sajidan, S., Baedhowi, B., Triyanto, T., Totalia, S. A., \& Masykuri, M. (2018). Peningkatan proses pembelajaran dan penilaian pembelajaran abad 21 dalam meningkatkan kualitas pembelajaran SMK. Jakarta: Directorate of Vocational Education, Directorate General of Primary an Secondary Education, Ministry of Education and Culture.

Samani, M. (2018). Vocational education in the era of Industry 4.0: An Indonesia sase. In Proceedings of the International Conference on Indonesian Technical Vocational Education and Association (APTEKINDO 2018) (pp. 45-47). Paris, France: Atlantis Press. https:// doi.org/10.2991/aptekindo-18.2018.10

Sharipova, N., \& Wesseler, M. (2018). Strengthening the innovative potential of project-based learning for TVET: The USPECH experience. In Technical and Vocational Education and Training (Vol. 28, pp. 27-42). Springer Nature. https://doi.org/10.1007/978-3-31973093-6_3

Slamet, S. (2010). Identifikasi sarana prasarana dan kondisi peralatan praktik mekanik otomotif SMK swasta di daerah polisi wilayah Bojonegoro dan Madiun. Teknologi Dan Kejuruan: Jurnal Teknologi, Kejuruan Dan Pengajarannya, 33(1), 107-120. https:// doi.org/10.17977/TK.V33I1.3092

Susanto, R., \& Sudira, P. (2016). Evaluasi sarana dan prasarana praktik teknik komputer dan jaringan di SMK Kabupaten Sukoharjo. Jurnal Pendidikan Vokasi, 6(1), 54-65. https://doi.org/10.21831/jpv.v6i1.8115 
Suyanta, S., Darmono, D., Prianto, E., Subiantoro, A. W., Dwandaru, W. S. B., Marwati, M., ... Syauqi, K. (2018). Desain pengembangan fasilitas sekolah di era Revolusi Industri 4.0. Jakarta: Direktorat Pembinaan SMK. Retrieved from http://psmk.kemdikbud.go.id/e pub/reader/4123/desain-pengembangan -fasilitas-sekolah-di-era-revolusiindustri-40

Syafrudie, H. A. (2016). Sarana praktikum sebagai lingkungan belajar yang menumbuhkan orientasi pemilihan pekerjaan siswa SMK. Teknologi Dan Kejuruan: Jurnal Teknologi, Kejuruan Dan Pengajarannya, 39(2), 163-170. https://doi.org/10.17977/TK.V39I2.779 0
Wijanarka, B. S. (2011). Conventional to virtual laboratory in vocational education. In Proceedings of International Conference on Vocational Education and Training (ICVET) 2011 (pp. 187-190). Yogyakarta: Yogyakarta State University. Retrieved from http:// staffnew.uny.ac.id/upload/131808327/p enelitian/Proceeding+ICVET+2011.pdf

Yasin, R. M., Nordin, N. M., Rahim, M. B., \& Yunus, F. A. N. (2014). Vocational education readiness in Malaysia on the use of e-portfolios. Journal of Technical Education and Training, 6(11), 57-71. Retrieved from https://publisher.uthm. edu.my/ojs/index.php/JTET/article/vie w/886/577 